\title{
Enhanced CREB-dependent gene expression increases the excitability of neurons in the basal amygdala and primes the consolidation of contextual and cued fear memory
}

\author{
Jose Viosca, ${ }^{1,2}$ Mikel Lopez de Armentia, ${ }^{1,2}$ Dragana Jancic, ${ }^{1}$ and Angel Barco ${ }^{1,3}$ \\ ${ }^{1}$ Instituto de Neurociencias de Alicante, Universidad Miguel Hernández-Consejo Superior de Investigaciones Científicas, Sant Joan \\ d'Alacant, 03550 Alicante, Spain
}

\begin{abstract}
Regulated expression of a constitutively active form of cAMP response element-binding protein (CREB), VP16-CREB, lowers the threshold for the late phase of long-term potentiation in the Schaffer collateral pathway in a de novo gene expression-independent manner, and increases the excitability and reduces afterhyperpolarization of neurons at the amygdala and the hippocampus. We explore the consequences of these changes on the consolidation of fear conditioning and find that the expression of VP16-CREB can bypass the requirement for de novo gene expression associated with longterm memory formation, suggesting that CREB-dependent gene expression is sufficient for fear memory consolidation.
\end{abstract}

[Supplemental material is available online at www.learnmem.org.]

Gene expression driven by the cAMP response element-binding protein (CREB) family of transcription factors, which is known to be important for memory storage in invertebrates, has also been proposed to play a role in regulating the conversion of different types of short-term memory to long-term memory in mammals (Josselyn and Nguyen 2005). However, the specific role of CREB on the consolidation of different forms of memory remains unclear. For example, although fear conditioning triggers CREB phosphorylation (Stanciu et al. 2001; Desmedt et al. 2003; Trifilieff et al. 2006) in the circuits that underlie the formation of fear memory, and CREB-driven gene expression in the amygdala and the hippocampus correlated with the formation of cued and contextual fear memories, respectively (Impey et al. 1998), the analysis of contextual conditioning in CREB-deficient mice has produced mixed results. Whereas some studies have found that CREB-deficient mutants exhibited impaired contextual fear (Bourtchuladze et al. 1994; Gass et al. 1998; Graves et al. 2002), others failed to reveal significant deficiencies in this task (Rammes et al. 2000; Pittenger et al. 2002; Balschun et al. 2003). Some of these discrepancies may have resulted from the fact that the expression of different members of the CREB family appears to be strongly co-regulated in the mouse, and, as a result, a reduction in the expression of CREB might be compensated for by the altered expression of other family members (Blendy et al. 1996; Mantamadiotis et al. 2002). Subsequent studies designed to overcome the obscuring effects of compensation have yielded a more precise examination of the role of CREB in fear memory. Thus, the inducible and transient repression of CREB in forebrain neurons specifically blocked the consolidation of long-term fear memories (Kida et al. 2002), and experiments using recombinant herpes viruses have demonstrated that the acute overexpression of CREB in the amygdala facilitated the formation of fear memory (Josselyn et al. 2001; Wallace et al. 2004).

\footnotetext{
${ }^{2}$ These authors contributed equally to this work.

${ }^{3}$ Corresponding author.

E-mail abarco@umh.es; fax 34-965-919492.

Article is online at http://www.learnmem.org/cgi/doi/10.1101//m.1254209.
}

Here, we explore the role of CREB activity in fear memory formation using an approach complementary to previous gainand loss-of-function studies. We investigate fear memory formation and the excitability of amygdalar neurons in a strain of bitransgenic animals, referred to as VP16-CREB ${ }^{\text {high }}$ mice, which express in a regulated and restricted manner VP16-CREB, a CREB variant whose strong transactivation activity is independent of the signaling cascades that regulate wild-type CREB (Barco et al. 2002; Lopez de Armentia et al. 2007). Expression of a constitutively active CREB variant in forebrain neurons using the CaMKII $\alpha$-tTA/ tetO system of double-transgenics (Mayford et al. 1996) provides a unique tool for evaluating the role of processes downstream of CREB and allows for the exploration of the sufficiency of CREBdependent gene expression in fear memory. In all our experiments, we used as a control littermate mice carrying either pCaMKII-tTA, tetO-VP16-CREB, or no transgene. Bitransgenic mice were housed and maintained in the same conditions as their control littermates, in single-sex cages on a light:dark cycle $(12 / 12 \mathrm{~h})$ with food and water available ad libitum, according to National and Institutional Animal Care and Use Committee guidelines. Doxycycline (dox) was administrated in the food at a dose of $40 \mathrm{mg} / \mathrm{kg}$ and removed at the indicated times.

Although previous physiological studies in VP16-CREB ${ }^{\text {high }}$ mice focused on the effects of the expression of VP16-CREB in CA1 pyramidal neurons (Barco et al. 2002; Lopez de Armentia et al. 2007) and cortical neurons of the visual cortex (Pham et al. 2004), VP16-CREB is also expressed in other neuronal populations, such as granular cells at the dentate gyrus and, to a lesser extent, neurons in the amygdala (Fig. 1A). Similar to pyramidal neurons in the CA1 subfield, neurons at the basal nucleus of the amygdala (BA) of VP16-CREB ${ }^{\text {high }}$ mice showed enhanced expression of CREB target genes involved in synaptic plasticity and memory formation, such as the c-fos (Fig. 1B).

Our previous research demonstrated that enhanced CREBmediated gene expression increased the intrinsic excitability of CA1 pyramidal neurons (Lopez de Armentia et al. 2007). To investigate whether similar changes in excitability also occur in the amygdala, we examined the firing pattern and membrane 

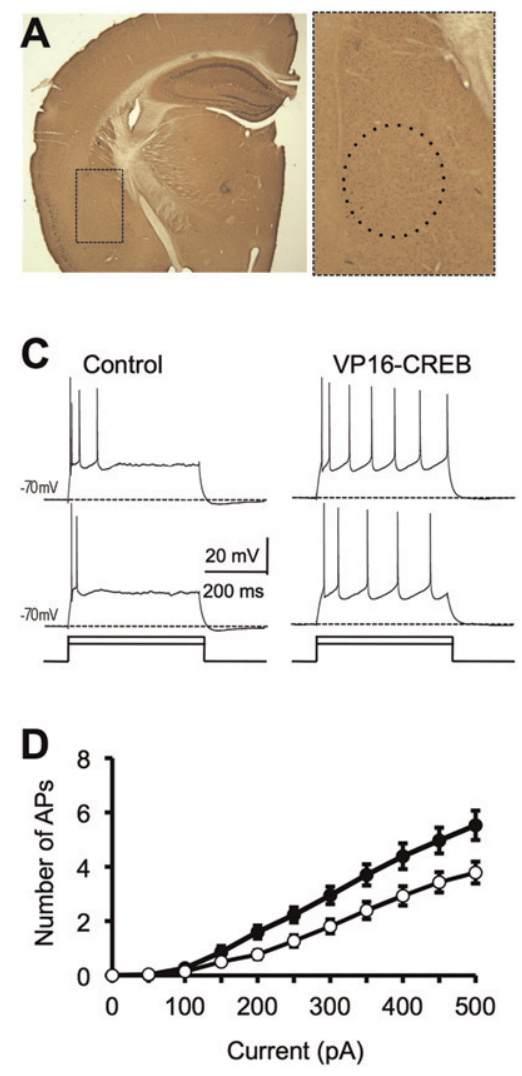

Figure 1. VP16-CREB enhances CREB-dependent gene expression and intrinsic excitability in fear conditioning circuits. $(A)$ (Left panel) Low-magnification image of brain vibratome coronal sections of a VP16-CREB-expressing mouse (1 wk off dox) immunostained using an antibody against the VP16 domain. (Right panel) High-magnification image shows the region framed in the left panel; (dotted circle) region of the basal nucleus of the amygdala in which the intracellular recordings were performed. Immunohistochemistry was performed as previously described (Barco et al. 2002). (B) Up-regulation of cfos expression in the amygdala of VP16-CREB ${ }^{\text {high }}$ mice. Double-labeling of neurons of control and VP16CREB mice using anti-c-fos polyclonal antibody and anti-VP16 monoclonal antibody. Scale bar, $35 \mu \mathrm{m}$. (C) Dox was removed from the mouse diet when the mice were 6-wk old; 7-10 d later the animals were anaesthetized with isoflurane and decapitated, and coronal slices that included the amygdala ( $300 \mu \mathrm{m})$ were processed as previously described (Lopez de Armentia et al. 2007). Patch-clamp pipettes were filled with intracellular solution containing $135 \mathrm{mM} \mathrm{KMeSO}_{4}, 8 \mathrm{mM} \mathrm{NaCl}, 10 \mathrm{mM}$ HEPES, 2 mM Mg 2 ATP, 0.3 $\mathrm{mM} \mathrm{Na}{ }_{3} \mathrm{GTP}$ ( $\mathrm{pH} 7.2$, osmolarity $290 \mathrm{mOsm} / \mathrm{kg}$ ). The panels show representative BA neuron response to 400 and 500 pA of depolarizing pulse in a control mouse (left panels) and a VP16-CREB high mouse (right panels). All recorded neurons had membrane potentials more negative than $-50 \mathrm{mV}$. Access resistance was 7-20 M $\Omega$ and was monitored throughout the experiment. No series resistance compensation was used. $(D)$ Average number of APs triggered in response to increasing depolarizing currents in neurons at the BA of the amygdala of VP16-CREB high mice $(\bullet, 57$ neurons, five mice) and control littermates $(\bigcirc, 56$ neurons, five mice) 7-10 d after dox removal. (E) Representative traces of currents underlying AHP in a BA pyramidal neuron of a VP16-CREB ${ }^{\text {high }}$ mouse (black) and a control littermate (gray). Averaged amplitude of the $I_{\text {mAHP }}$ (left panel) and the $I_{\text {SAHP }}$ (right panel) of the same neurons represented in panel $D$. (Black bars) VP16-CREB ${ }^{\text {high }}$ mice; (white bars) control littermates; $(*) P<0.05$.

properties of neurons in the basal nucleus (BA) of the amygdala. Whole-cell recordings in BA neurons $10 \mathrm{~d}$ after dox removal revealed no difference in passive membrane properties between transgenic mice and their littermates (Table 1). However, the extransgenic mice were undistinguishable from control littermates in a modified SHIRPA primary screen and in the open-field, rotarod, and elevated plus maze tasks (Supplemental Table 1; Supplemental Fig. S1), indicating that neither transgene expression nor the

Table 1. Electrophysiological properties of neurons at the BA

\begin{tabular}{|c|c|c|c|c|c|c|c|}
\hline & $\begin{array}{c}E_{m} \\
(m V)\end{array}$ & $\mathbf{R}_{\text {in }}$ & $\underset{(\mathrm{ms})}{\tau}$ & $\begin{array}{c}\mathrm{AP}_{\text {amplitude }} \\
(\mathrm{mV})\end{array}$ & $\begin{array}{l}\mathrm{AP}_{50} \\
(\mathrm{~ms})\end{array}$ & $\begin{array}{c}\mathrm{d} V / \mathrm{d} t_{\max } \\
(\mathrm{V} / \mathrm{s})\end{array}$ & $\begin{array}{c}\text { Threshold } \\
(\mathrm{mV})\end{array}$ \\
\hline VP16-CREB $^{\text {high }}(n=57,5)$ & $-69 \pm 0.8$ & $180 \pm 16.9$ & $30 \pm 1.6$ & $112 \pm 0.7$ & $1.30 \pm 0.05$ & $243 \pm 6.1$ & $-32 \pm 0.7$ \\
\hline Control $(n=56,5)$ & $-70 \pm 0.8$ & $147 \pm 16.6$ & $26 \pm 1.5$ & $111 \pm 0.8$ & $1.20 \pm 0.03$ & $248 \pm 5.9$ & $-34 \pm 0.6$ \\
\hline$P$-value & 0.20 & 0.15 & 0.07 & 0.40 & 0.07 & 0.53 & 0.06 \\
\hline
\end{tabular}

$\mathrm{E}_{m}$ : membrane potential; $\mathrm{R}_{\mathrm{in}}$ : membrane resistance; $\tau$ : membrane time constant; $\mathrm{AP}$ : action potential; $\mathrm{AP}_{50}$ : AP duration at $50 \%$ of amplitude; $\mathrm{d} V / \mathrm{d} t \mathrm{max}$ : maximum rate of depolarization. 
concurrent alterations in neuronal physiology initially affected anxiety, locomotor activity, or motor coordination.

In contextual fear conditioning, the animal learns to fear a specific context (conditioned stimulus or CS) in which it received an electric foot shock (unconditioned stimulus or US), whereas in cued fear conditioning, the mice associate a specific tone (CS) with the electric shock. Memory was evaluated in both cases by measuring the percentage of time that the animal freezes when re-exposed to the CS. Since CREB overexpression has been shown to facilitate fear memory formation (Josselyn et al. 2001; Wallace et al. 2004; Han et al. 2008), in order to specifically assess whether VP16-CREB expression can prime memory formation, rendering its consolidation protein synthesis independent, we used a strong training protocol (0.7-mA foot shock) that elicited a similar and robust freezing response in bitransgenic animals and control siblings $24 \mathrm{~h}$ after training, both in the contextual (control [7 animals per group]: $63.86 \pm 4.7 \%$, VP16-CREB ${ }^{\text {high }}[9$ animals per group]: $\left.62.33 \pm 5.0 \%, t_{(14)}=0.313, P=0.83\right)$ and cued conditioning tasks (control: $70.86 \pm 8.0 \%$, VP16-CREB ${ }^{\text {high }}$ : $\left.63.89 \pm 4.31 \%, t_{(14)}=1.120, P=0.43\right)$. In this way, we were sure that mutant and control siblings injected with vehicle had similar freezing, which facilitates the interpretation of the results in anisomycin-injected mice. We then assessed in independent groups of mice the effect of the protein synthesis blocker anisomycin in 24-h memory in VP16-CREB ${ }^{\text {high }}$ mice and control littermates. We found that contextual fear conditioning in VP16CREB $^{\text {high }}$ mice was largely resistant to inhibition by anisomycin. When this drug was injected immediately after training, it reduced contextual memory strength in control animals (Fig. 2A; control mice injected with vehicle: $67.6 \pm 4.5 \%$ vs. anisomycin: $34.2 \pm$ $4.8 \%, P<0.001$ ), but had no effect on VP16-CREB ${ }^{\text {high }}$ mice (Fig. $2 \mathrm{~A}$; VP16-CREB ${ }^{\text {high }}$ mice injected with vehicle: $70.3 \pm 4.6 \%$ vs. anisomycin: $58.3 \pm 5.5 \%, P=0.608)$. Moreover, freezing in control and VP16-CREB ${ }^{\text {high }}$ mice injected with anisomycin was significantly different $(P=0.006)$, and ANOVA revealed a significant genotype $\times$ treatment interaction $\left(F_{(1,63)}=4.666, P=0.035\right)$, confirming that anisomycin differentially affected contextual memory retention in control and VP16-CREB ${ }^{\text {high }}$ mice.

Post-training injection of anisomycin also interfered with the consolidation of cued fear memory in wild-type animals (Fig. 2B; control mice vehicle: $73.3 \pm 3.6 \%$ vs. anisomycin: $36.3 \pm 6.0 \%$, $P<0.001$ ), but did not block memory consolidation in bitransgenic animals (Fig. 2B; VP16-CREB ${ }^{\text {high }}$ mice vehicle: $77.5 \pm 4.3 \%$, vs. anisomycin: $67.2 \pm 7.2 \%, P=n s$ ). Like in the contextual memory task, control mice injected with anisomycin froze more than VP16-CREB ${ }^{\text {high }}$ mice injected with the drug $(P=0.001)$, and a significant genotype $\times$ treatment interaction confirmed that memory retention was differentially affected by anisomycin $\left(F_{(1,63)}=5.815, P=0.019\right)$. These results suggest that plasticity factors required for the consolidation of contextual and cued fear memory need to be induced in the case of control mice, but could be present in the basal state in VP16-CREB-expressing neurons and, therefore, bitransgenic mice can bypass the requirement for de novo gene expression associated with this form of long-term memory.

Our study provides the first evidence for modulation by CREB activity of intrinsic excitability in neurons at the BA, a critical component of the fear memory circuit (Sah et al. 2003). This result together with the recent findings in the nucleus accumbens, locus ceruleus, and hippocampus (Dong et al. 2006; Han et al. 2006; Lopez de Armentia et al. 2007; Huang et al. 2008) suggests that regulation of intrinsic plasticity is a major function of CREB conserved in different types of neurons.

In agreement with previous studies showing that CREB activity can provide the building blocks necessary for the consolidation of synaptic plasticity processes (Casadio et al. 1999; Barco

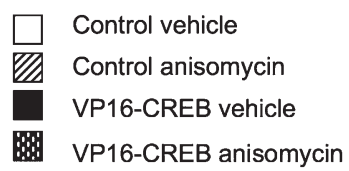

A
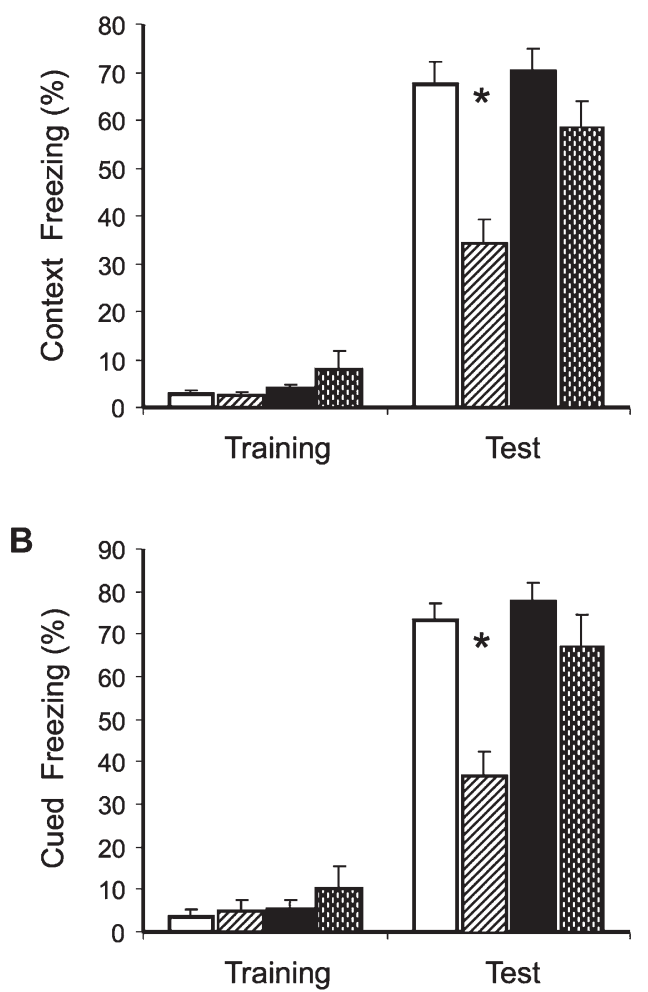

Figure 2. The consolidation of contextual and cued fear memory in VP16-CREB ${ }^{\text {high }}$ mice is resistant to protein synthesis inhibition. One week after dox removal, 3- to 4-mo-old male mice were placed in the conditioning chamber for 2 min before the onset of a tone at $2800 \mathrm{~Hz}$, $85 \mathrm{~dB}$, which lasted for $30 \mathrm{sec}$. The last $2 \mathrm{sec}$ of the tone was paired with the US, a single foot shock. After an additional $30 \mathrm{sec}$ in the chamber, mice were immediately injected with anisomycin $(150 \mathrm{mg} / \mathrm{kg})$ or vehicle (control vehicle: $n=17$; control anisomycin: $n=19$; VP16-CREB high vehicle: $n=16$; VP16-CREB ${ }^{\text {high }}$ anisomycin: $n=15$ ) and returned to their home cage. One day later the mice were tested for contextual and cued fear memory. Contextual conditioning was assessed by scoring freezing behavior in the context in which mice were trained using a weight transducer system (Fear Conditioning System, Panlab S.L.). Cued conditioning was assessed $2-3 \mathrm{~h}$ after contextual conditioning by scoring freezing behavior in a second context and delivering the same tone used during training. (A) Contextual fear memory in VP16-CREB high mice is resistant to protein synthesis inhibition. (B) Cued fear memory in VP16CREB mice is also resistant to protein synthesis inhibition. (*) Significant differences compared with all other three groups. Two-way ANOVAs were used for determining genotype $\times$ treatment interactions. For comparison between groups, one-way ANOVAs followed by Bonferroni post-hoc were used.

et al. 2002, 2005), we also found that enhanced CREB activity led to the formation of memories for contextual and cued fear conditioning that were more resistant to interference with a protein synthesis inhibitor. This finding supports a role for synaptic tagging and capture (STC) mechanisms in associative memory. The STC hypothesis distinguishes two independent and essential events required for the consolidation of changes in synaptic strength: (1) synaptic activation or tagging and (2) de novo gene expression. Consolidation results from the interaction of both processes, which is referred to as synaptic capture (Frey and Morris 1997; Barco et al. 2008). According to this hypothesis, it is 
therefore possible to achieve consolidation even if the synaptic tag and the burst of gene expression are initiated independently by different sorts of stimuli. Interestingly, a recent study showed that a weak inhibitory avoidance training, which induces short- but not long-term memory, could be consolidated into long-term memory by exploration of a novel environment occurring close in time to the training session. This reinforcement was blocked by anisomycin applied before exploration, providing the first experimental evidence for behavioral tagging (Moncada and Viola 2007). Similarly, hippocampal early phase of LTP (E-LTP) can be also behaviorally reinforced into L-LTP by novelty exploration in a protein synthesis-dependent manner (Straube et al. 2003). As in our study, those experiments indicate that previously synthesized plasticity-related proteins can be efficiently used for the consolidation of ensuing memory.

The physiological activation of CREB in neuronal populations involved in the acquisition and storage of fear memory might favor memory formation as a result of the additive effects of two changes in neuronal physiology: the increase in intrinsic excitability that could contribute to reducing the threshold for stable synaptic changes and facilitating learning (Josselyn et al. 2001; Wallace et al. 2004; Han et al. 2008), and the overexpression of plasticityrelated proteins that would prime the synapses and enable the rapid consolidation of learning-related plasticity changes (Barco et al. 2002, 2005). Although we have not investigated whether L-LTP is facilitated in amygdalar circuits, we speculate that similarly to the changes in intrinsic excitability, which are observed both in amygdalar and hippocampal neurons, long-term synaptic plasticity may also be facilitated in BA neurons. This could explain the resistance to anisomycin observed in the consolidation of cued fear conditioning, a task that is independent of hippocampal function.

Our results also contribute to the current debate concerning the role of de novo protein synthesis in memory consolidation and in particular the use of the drug anisomycin in such studies (Alberini 2008; Gold 2008; Hernandez and Abel 2008; Rudy 2008). The resistance observed in VP16-CREB mice argues against the idea that anisomycin-induced amnesia results from the toxic and proapototic effects of this drug (Rudy 2008).

In conclusion, previous studies have suggested that CREB activity is necessary for the consolidation of fear memory; we have now demonstrated that it may also be sufficient. The previous activation of CREB-dependent gene expression enabled the rapid consolidation of contextual and cued fear memory, bypassing the gene expression-dependent step normally associated with longterm memory processes.

\section{Acknowledgments}

We thank Eric R. Kandel, Gael Malleret, and members of the Barco laboratory for helpful discussion and critical reading of the manuscript. We also thank Román Olivares for technical assistance on mice genotyping. J.V. holds a fellowship from the Generalitat Valenciana (BFPI06/316). This work was supported by European Commission grant MEXT-CT-2003-509550, Spanish MEC grants BFU2005-00286 and CSD2007-00023, Generalitat Valenciana grant AP-046/08, and grants from Fundació La Marató de TV3 and Fundación Ramón Areces.

\section{References}

Alberini, C.M. 2008. The role of protein synthesis during the labile phases of memory: Revisiting the skepticism. Neurobiol. Learn. Mem. 89: 234-246.

Balschun, D., Wolfer, D.P., Gass, P., Mantamadiotis, T., Welzl, H., Schutz, G., Frey, J.U., and Lipp, H.P. 2003. Does cAMP response element-binding protein have a pivotal role in hippocampal synaptic plasticity and hippocampus-dependent memory? J. Neurosci. 23: 6304-6314.

Barco, A., Alarcon, J.M., and Kandel, E.R. 2002. Expression of constitutively active CREB protein facilitates the late phase of long-term potentiation by enhancing synaptic capture. Cell 108: 689-703.
Barco, A., Patterson, S., Alarcon, J.M., Gromova, P., Mata-Roig, M., Morozov, A., and Kandel, E.R. 2005. Gene expression profiling of facilitated L-LTP in VP16-CREB mice reveals that BDNF is critical for the maintenance of LTP and its synaptic capture. Neuron 48: 123-137.

Barco, A., Lopez de Armentia, M., and Alarcon, J.M. 2008. Synapse-specific stabilization of plasticity processes: The synaptic tagging and capture hypothesis revisited 10 years later. Neurosci. Biobehav. Rev. 32: 831-851.

Blendy, J.A., Kaestner, K.H., Schmid, W., Gass, P., and Schutz, G. 1996. Targeting of the CREB gene leads to up-regulation of a novel CREB mRNA isoform. EMBO J. 15: 1098-1106.

Bourtchuladze, R., Frenguelli, B., Blendy, J., Cioffi, D., Schutz, G., and Silva A.J. 1994. Deficient long-term memory in mice with a targeted mutation of the cAMP-responsive element-binding protein. Cell 79: 59-68.

Casadio, A., Martin, K.C., Giustetto, M., Zhu, H., Chen, M., Bartsch, D., Bailey, C.H., and Kandel, E.R. 1999. A transient, neuron-wide form of CREB-mediated long-term facilitation can be stabilized at specific synapses by local protein synthesis. Cell 99: 221-237.

Desmedt, A., Hazvi, S., and Dudai, Y. 2003. Differential pattern of cAMP response element-binding protein activation in the rat brain after conditioned aversion as a function of the associative process engaged: Taste versus context association. J. Neurosci. 23: 6102-6110.

Dong, Y., Green, T., Saal, D., Marie, H., Neve, R., Nestler, E.J., and Malenka, R.C. 2006. CREB modulates excitability of nucleus accumbens neurons Nat. Neurosci. 9: 475-477.

Frey, U. and Morris, R.G. 1997. Synaptic tagging and long-term potentiation. Nature 385: 533-536.

Gass, P., Wolfer, D.P., Balschun, D., Rudolph, D., Frey, U., Lipp, H.P., and Schutz, G. 1998. Deficits in memory tasks of mice with CREB mutations depend on gene dosage. Learn. Mem. 5: 274-288.

Gold, P.E. 2008. Protein synthesis inhibition and memory: Formation vs. amnesia. Neurobiol. Learn. Mem. 89: 201-211.

Graves, L., Dalvi, A., Lucki, I., Blendy, J.A., and Abel, T. 2002. Behavioral analysis of CREB $\alpha \Delta$ mutation on a B6/129 F1 hybrid background. Hippocampus 12: 18-26.

Han, M.H., Bolanos, C.A., Green, T.A., Olson, V.G., Neve, R.L., Liu, R.J., Aghajanian, G.K., and Nestler, E.J. 2006. Role of cAMP response element-binding protein in the rat locus ceruleus: Regulation of neuronal activity and opiate withdrawal behaviors. J. Neurosci. 26: 4624-4629.

Han, J.H., Yiu, A.P., Cole, C.J., Hsiang, H.L., Neve, R.L., and Josselyn, S.A. 2008. Increasing CREB in the auditory thalamus enhances memory and generalization of auditory conditioned fear. Learn. Mem. 15: 443-453.

Hernandez, P.J. and Abel, T. 2008. The role of protein synthesis in memory consolidation: Progress amid decades of debate. Neurobiol. Learn. Mem. 89: 293-311.

Huang, Y.H., Lin, Y., Brown, T.E., Han, M.H., Saal, D.B., Neve, R.L., Zukin, R.S., Sorg, B.A., Nestler, E.J., Malenka, R.C. , et al. 2008. CREB modulates the functional output of nucleus accumbens neurons: A critical role of $\mathrm{N}$-methyl-D-aspartate glutamate receptor (NMDAR) receptors. J. Biol. Chem. 283: 2751-2760.

Impey, S., Smith, D.M., Obrietan, K., Donahue, R., Wade, C., and Storm, D.R. 1998. Stimulation of cAMP response element (CRE)-mediated transcription during contextual learning. Nat. Neurosci. 1: 595-601.

Josselyn, S.A. and Nguyen, P.V. 2005. CREB, synapses and memory disorders: Past progress and future challenges. Curr. Drug Target. CNS Neurol. Disord. 4: 481-497.

Josselyn, S.A., Shi, C., Carlezon Jr., W.A., Neve, R.L., Nestler, E.J., and Davis, M. 2001. Long-term memory is facilitated by cAMP response elementbinding protein overexpression in the amygdala. J. Neurosci. 21: 24042412 .

Kida, S., Josselyn, S.A., de Ortiz, S.P., Kogan, J.H., Chevere, I., Masushige, S., and Silva, A.J. 2002. CREB required for the stability of new and reactivated fear memories. Nat. Neurosci. 5: 348-355.

Lopez de Armentia, M., Jancic, D., Olivares, R., Alarcon, J.M., Kandel, E.R., and Barco, A. 2007. cAMP response element-binding protein-mediated gene expression increases the intrinsic excitability of CA1 pyramidal neurons. J. Neurosci. 27: 13909-13918.

Mantamadiotis, T., Lemberger, T., Bleckmann, S.C., Kern, H., Kretz, O., Martin Villalba, A., Tronche, F., Kellendonk, C., Gau, D., Kapfhammer, J., et al. 2002. Disruption of CREB function in brain leads to neurodegeneration. Nat. Genet. 31: 47-54.

Mayford, M., Bach, M.E., Huang, Y.Y., Wang, L., Hawkins, R.D., and Kandel, E.R. 1996. Control of memory formation through regulated expression of a CaMKII transgene. Science 274: 1678-1683.

Moncada, D. and Viola, H. 2007. Induction of long-term memory by exposure to novelty requires protein synthesis: Evidence for a behavioral tagging. J. Neurosci. 27: 7476-7481.

Pham, T.A., Graham, S.J., Suzuki, S., Barco, A., Kandel, E.R., Gordon, B., and Lickey, M.E. 2004. A semi-persistent adult ocular dominance plasticity in visual cortex is stabilized by activated CREB. Learn. Mem. 11: 738747. 
Pittenger, C., Huang, Y.Y., Paletzki, R.F., Bourtchouladze, R., Scanlin, H., Vronskaya, S., and Kandel, E.R. 2002. Reversible inhibition of CREB/ATF transcription factors in region CA1 of the dorsal hippocampus disrupts hippocampus-dependent spatial memory. Neuron 34: 447-462.

Rammes, G., Steckler, T., Kresse, A., Schutz, G., Zieglgansberger, W., and Lutz, B. 2000. Synaptic plasticity in the basolateral amygdala in transgenic mice expressing dominant-negative cAMP response element-binding protein (CREB) in forebrain. Eur. J. Neurosci. 12: 2534 2546.

Rudy, J.W. 2008. Is there a baby in the bathwater? Maybe: Some methodological issues for the de novo protein synthesis hypothesis. Neurobiol. Learn. Mem. 89: 219-224.

Sah, P., Faber, E.S., Lopez De Armentia, M., and Power, J. 2003. The amygdaloid complex: Anatomy and physiology. Physiol. Rev 83: 803-834.

Stanciu, M., Radulovic, J., and Spiess, J. 2001. Phosphorylated cAMP response element binding protein in the mouse brain after fear conditioning: Relationship to Fos production. Brain Res. Mol. Brain Res. 94: $15-24$.

Straube, T., Korz, V., Balschun, D., and Frey, J.U. 2003. Requirement of $\beta-$ adrenergic receptor activation and protein synthesis for LTPreinforcement by novelty in rat dentate gyrus. J. Physiol. 552: 953-960. Trifilieff, P., Herry, C., Vanhoutte, P., Caboche, J., Desmedt, A., Riedel, G., Mons, N., and Micheau, J. 2006. Foreground contextual fear memory consolidation requires two independent phases of hippocampal ERK/ CREB activation. Learn. Mem. 13: 349-358.

Wallace, T.L., Stellitano, K.E., Neve, R.L., and Duman, R.S. 2004. Effects of cyclic adenosine monophosphate response element binding protein overexpression in the basolateral amygdala on behavioral models of depression and anxiety. Biol. Psychiatry 56: 151-160.

Received October 10, 2008; accepted in revised form December 20, 2008. 


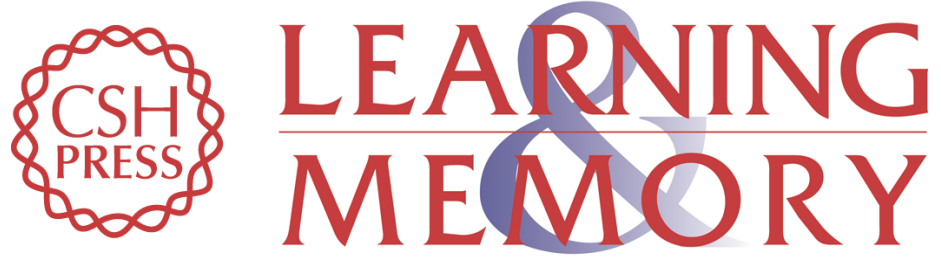

\section{Enhanced CREB-dependent gene expression increases the excitability of neurons in the basal amygdala and primes the consolidation of contextual and cued fear memory}

Jose Viosca, Mikel Lopez de Armentia, Dragana Jancic, et al.

Learn. Mem. 2009, 16:

Access the most recent version at doi:10.1101/lm.1254209

Related Content Chronic enhancement of CREB activity in the hippocampus interferes with the retrieval of spatial information

Jose Viosca, Gaël Malleret, Rusiko Bourtchouladze, et al.

Learn. Mem. March , 2009 16: 198-209

References This article cites 35 articles, 12 of which can be accessed free at: http://learnmem.cshlp.org/content/16/3/193.full.html\#ref-list-1

Articles cited in:

http://learnmem.cshlp.org/content/16/3/193.full.html\#related-urls

License

Email Alerting Receive free email alerts when new articles cite this article - sign up in the box at the Service top right corner of the article or click here. 